\title{
Relation of hyperlipidemia in serum and loss of high density lipoproteins in urine in the nephrotic syndrome
}

\author{
Dieter Jüngst, Wolfgang H. Caselmann, Peter Kutschera \\ and Peter Weisweiler \\ Department of Medicine II, Klinikum Grosshadern, University of Munich. Munich (FRG)
}

(Received 1 May 1986; revision received 15 May 1987; accepted after revision 17 May 1987)

Key words: Hyperlipoproteinemia; Lipoproteinuria; Nephrotic syndrome; Very low density lipoprotein (VLDL); Low density lipoprotein (LDL); High density lipoprotein (HDL)

\section{Summary}

The mechanism leading to hyperlipidemia in the nephrotic syndrome is not fully understood but may be related in part to loss of high density lipoproteins in the urine of patients with nephrosis. To prove this hypothesis, we compared serum lipoprotein profiles with the excretion of high density lipoproteins in urine in 19 nephrotic patients. Serum cholesterol ranged from 19-152 (median value 45) $\mathrm{mg} / \mathrm{dl}$ in very low density lipoproteins (VLDL), from 130-443 (median 186) mg/dl in low density lipoproteins (LDL) and from 19-64 (median 33) $\mathrm{mg} / \mathrm{dl}$ in high density lipoproteins (HDL). Hyperlipoproteinemia was found in 17 patients, which was classified as phenotype IIa (Fredrickson) in 2, as phenotype IIb in 9 and as phenotype IV in 6 subjects. Two patients showed normal lipoprotein patterns. VLDL- and LDL-cholesterol were not found in detectable amounts in urine, whereas HDL-cholesterol was measured in low concentrations from $0.1-8.3 \mathrm{mg} / 24$ $\mathrm{h}$ in all samples. There was no correlation between serum HDL-cholesterol and urinary HDL-cholesterol, but a positive correlation between serum LDL-cholesterol and urinary HDL-cholesterol $(r=+0.54, p<0.05)$. However, the total amount of the daily urinary loss of HDL $(<1 \%$ of total plasma HDL) seems not to be sufficient to explain hyperlipoproteinemia in the nephrotic syndrome.

Correspondence and reprint requests to: Dieter Jüngst, M.D., Department of Medicine II, Klinikum Grosshadern, University of Munich, P.O.B. 701 260, D-8000 München 70, FRG. 


\section{Introduction}

The mechanisms causing hyperlipidemia in the nephrotic syndrome are complex and include both altered catabolism and enhanced synthesis of lipids [1-6]. In these patients an elevated excretion of urinary lipids has long been recognized $[7,8]$ and it was suggested that loss of high density lipoproteins in urine might be related to hyperlipoproteinemia in serum $[9,10]$.

Although HDL was identified in urine of nephrotic patients [11], quantitative measurements have not yet been done. We, therefore, compared serum lipoprotein patterns in patients with untreated nephrotic syndrome with the excretion of high density lipoproteins in urine. Quantitation of urinary HDL was performed by cholesterol measurements in HDL fractions after ultrafiltration and gel chromatography of the urinary samples. Although our results show a positive correlation between serum LDL-cholesterol and urinary HDL-cholesterol the amount of the daily urinary loss of HDL seems not to be sufficient to explain the hyperlipidemia in patients with nephrotic syndrome.

\section{Materials and methods}

\section{Patients}

Nineteen patients (age 17 to $69 \mathrm{yr}$ ) with nephrotic syndrome of various origins were included in the study (Table I). Diagnoses were established by the laboratory finding of proteinuria $(>2 \mathrm{~g} / 24 \mathrm{~h})$ as well as renal sonography, intravenous urography, cystoscopy and histological examination of biopsies. Five patients suffered from diabetic nephropathy, 4 had perimembranous, 3 epimembranous, 2 mesangial proliferative, 1 membranous-proliferative and 1 proliferative glomerulonephritis. Two renal biopsies showed focal glomerulosclerosis and 1 minimal glomerular lesions.

In each patient the $24 \mathrm{~h}$-urine and blood specimens after fasting overnight were collected at the same time. No steroids were applied and no restrictive diets were kept during the collection period.

\section{Chemical assays}

Total serum albumin was measured with a Technicon SMA 12/60 Multiple Analyzer. Total serum cholesterol and triglyceride determinations were performed enzymatically with commercial test kits (Boehringer, Mannheim, FRG) [12,13]. Urinary protein was determined with the Biuret reagent [14]. Total cholesterol in urine was analyzed by gas-liquid chromatography using a Perkin Elmer chromatograph (model 900) with flame ionization detectors and a $180 \mathrm{~cm} \times 2 \mathrm{~mm}, 1 \%$ XE 60 column, column temperature $220^{\circ} \mathrm{C}$, as described previously [15].

\section{Separation of serum lipoproteins}

Serum lipoproteins were separated at $d=1.006 \mathrm{~g} / \mathrm{ml}$ by preparative ultracentrifugation $\left(105000 \times g, 22 \mathrm{~h}, 4^{\circ} \mathrm{C}\right)$ [16]. VLDL was removed by slicing the tube. In the infranate, LDL and HDL were further separated by precipitation with sodium phosphotungstate and magnesium chloride [17]. 
TABLE I

Serum albumin and lipids in 19 nephrotic patients

\begin{tabular}{|c|c|c|c|c|c|c|c|c|}
\hline Patients & Age & Sex & $\begin{array}{l}\text { Serum } \\
\text { albumin } \\
(\mathrm{g} / \mathrm{d} 1)\end{array}$ & $\begin{array}{l}\text { Serum } \\
\text { choles- } \\
\text { terol } \\
(\mathrm{mg} / \mathrm{dl})\end{array}$ & $\begin{array}{l}\text { Serum } \\
\text { trigly- } \\
\text { cerides } \\
(\mathrm{mg} / \mathrm{d})\end{array}$ & $\begin{array}{l}\text { VLDL- } \\
\text { choles- } \\
\text { terol } \\
(\mathrm{mg} / \mathrm{dl})\end{array}$ & $\begin{array}{l}\text { LDL- } \\
\text { choles- } \\
\text { terol } \\
(\mathrm{mg} / \mathrm{dl})\end{array}$ & $\begin{array}{l}\text { HDL- } \\
\text { choles- } \\
\text { terol } \\
(\mathrm{mg} / \mathrm{dl})\end{array}$ \\
\hline 1. B.R. & 69 & f & 3.7 & 197 & 261 & 45 & 135 & 26 \\
\hline 2. B.M. & 34 & $\mathrm{~m}$ & 3.5 & 249 & 253 & 71 & 186 & 36 \\
\hline 3. B.H. & 59 & m & 2.6 & 464 & 570 & 103 & 183 & 38 \\
\hline 4. D.A. & 55 & $\mathrm{~m}$ & 3.0 & 316 & 88 & 25 & 230 & 37 \\
\hline 5. F.J. & 47 & $\mathrm{~m}$ & 1.8 & 693 & 630 & 152 & 418 & 40 \\
\hline 6. H.W. & 50 & $\mathbf{m}$ & 2.6 & 284 & 234 & 61 & 163 & 29 \\
\hline 7. H.F. & 42 & $\mathbf{m}$ & 3.7 & 284 & 326 & 69 & 218 & 21 \\
\hline 8. H.A. & 40 & $\mathbf{m}$ & 4.1 & 232 & 213 & 41 & 144 & 56 \\
\hline 9. H.J. & 69 & f & 4.0 & 245 & 349 & 61 & 150 & 21 \\
\hline 10. K.A. & 39 & $\mathrm{~m}$ & 2.7 & 403 & 242 & 68 & 306 & 30 \\
\hline 11. K.Z. & 44 & $\mathbf{m}$ & 2.5 & 340 & 264 & 63 & 244 & 19 \\
\hline 12. L.S. & $\$ 2$ & f & 1.7 & 485 & 465 & 135 & 300 & 50 \\
\hline 13. L.A. & 22 & $\mathrm{~m}$ & 4.7 & 221 & 137 & 33 & 141 & 33 \\
\hline 14. M.M. & 21 & $f$ & 3.3 & 191 & 153 & 28 & 130 & 32 \\
\hline 15. N.F. & 62 & $\mathbf{m}$ & 2.4 & 422 & 327 & 75 & 331 & 38 \\
\hline 16. R.M. & 37 & $\mathrm{~m}$ & 3.2 & 209 & 143 & 21 & 151 & 37 \\
\hline 17. S.J. & 50 & $\mathrm{~m}$ & 3.2 & 197 & 253 & 37 & 154 & 23 \\
\hline 18. S.E. & 69 & f & 3.0 & 198 & 161 & 19 & 191 & 19 \\
\hline 19. W.C. & 17 & f & 2.1 & 543 & 113 & 44 & 443 & 64 \\
\hline \multicolumn{3}{|l|}{ Range } & $1.7-4.7$ & $191-693$ & $88-630$ & $19-152$ & $130-443$ & $19-64$ \\
\hline \multicolumn{3}{|c|}{ Median value } & 3.0 & 284 & 253 & 45 & 186 & 33 \\
\hline \multicolumn{3}{|c|}{ Normal value } & $3.7-4.8$ & $<230$ & $<200$ & $<30$ & $<180$ & $>\operatorname{m~} 35 / f 40$ \\
\hline
\end{tabular}

Isolation of urinary high density lipoproteins

Within $1 \mathrm{~h}$ after the collection the $24 \mathrm{~h}$-urine samples were passed through a Selecta filter no. 1117 1/2 (Schleicher Schüll, Dassel, FRG) in order to remove cellular debris of 5 to $10 \mu \mathrm{m}$ in diameter. Then, $\mathrm{NaCl}$ was added up to a final concentration of $0.56 \mathrm{~mol} / 1$ to precipitate the Tamm-Horsefall mucoprotein [18], which was removed by centrifugation for $10 \mathrm{~min}$ at $8000 \mathrm{rpm}$. Before the supernatant $\left(90 \%\right.$ of the volume) was concentrated by ultrafiltration at $4^{\circ} \mathrm{C}$ to a final volume of 3 to $5 \mathrm{ml}$ in a stirred cell (Amicon, Witten, FRG; models 402 and 52) with $\mathrm{PM} 10$ membranes, $0.2 \mathrm{~g}$ sodium azide $\left(\mathrm{NaN}_{3}\right)$ and $0.05 \mathrm{mmol}$ phenylmethanesulfonyl fluoride (PMSF) in 100\% isopropanol were added per $1000 \mathrm{ml}$ of urine to avoid bacterial and enzymatic degradation. Aliquots of 2 to $3 \mathrm{ml}$ of the concentrated urine were used for gel chromatography on a $100 \times 2.5 \mathrm{~cm}$ Sephadex G-100 column. Elution was performed with $0.15 \mathrm{~mol} / 1 \mathrm{NaCl}, 0.1 \mathrm{~g} / 1 \mathrm{Na}_{2}$-EDTA, $0.2 \mathrm{~g} / 1 \mathrm{NaN}_{3}$ and $0.05 \mathrm{mmol} / 1 \mathrm{PMSF}$ at $\mathrm{pH} 7.0$ [19]. Usually 70 to $808-\mathrm{ml}$ fractions were collected. The absorbance at $280 \mathrm{~nm}$ was recorded with a spectrophotometer (Beckman, Fullerton, CA, model 24) and total cholesterol was measured by gas-liquid chromatography. The cholesterol containing fractions were pooled and 
concentrated to 3 to $5 \mathrm{ml}$. After rechromatography on a $120 \times 1.8 \mathrm{~cm}$ Biogel $\mathrm{A} 5 \mathrm{~m}$ column about $508-\mathrm{ml}$ fractions were collected. The absorbance at $280 \mathrm{~nm}$ and the cholesterol concentrations were plotted graphically. The elution pattern revealed 2 or 3 peaks, which were pooled and concentrated each to 0.5 to $2 \mathrm{ml}$.

Recovery studies for cholesterol showed a total loss between 30 and $50 \%$ at the end of the fractionation.

\section{Immunodiffusion}

Ouchterlony immunodiffusion was performed in $15 \mathrm{~g} / 1$ bactoagar $(0.02 \mathrm{~mol} / 1$ sodium diethylbarbiturate, $0.03 \mathrm{~mol} / \mathrm{l}$ sodium acetate), $\mathrm{pH}$ 8.6. The glass plates were incubated for $48 \mathrm{~h}$ at $20^{\circ} \mathrm{C}$. The staining was done with azokarmine B (Sigma, München, FRG). We tested against antisera against $\alpha_{1}$ - and $\beta$-lipoproteins (Behring, Marburg, FRG) identical to apoHDL and apoLDL, respectively.

\section{Statistical analysis}

Using ranges and median values the statistical analysis of our data was carried out applying the $t$-test, the Spearman rank correlation coefficient and the analysis of the regression line [20].

\section{Results}

\section{Serum albumin. lipids and lipoproteins}

Single values of serum albumin, total cholesterol, triglycerides, VLDL-, LDLand HDL-cholesterol of 19 patients with nephrotic syndrome are listed in Table I. In 14 out of 19 serum samples hypoalbuminemia was found. Only 4 patients had normal serum cholesterol and triglyceride concentrations, one of which showed a regular cholesterol distribution on the three main lipoprotein classes. In the remaining 18 patients at least one lipid parameter was abnormal. In 10 patients we found decreased plasma HDL-cholesterol levels and in 11 elevated plasma LDL-cholesterol concentrations.

\section{Urinary protein, total cholesterol and HDL-cholesterol}

The total urinary protein excretion varied from 2.0 to $24.5 \mathrm{~g} / 24 \mathrm{~h}$ (median value $4.9 \mathrm{~g} / 24 \mathrm{~h}$ ) and total urinary cholesterol concentrations from $3.1 \mathrm{mg}$ to $68.7 \mathrm{mg} / 24$ h (median value $20.0 \mathrm{mg} / 24 \mathrm{~h}$ ) (Table II).

For isolation of urinary HDL lower molecular proteins were separated from urinary lipids by gel filtration on a Sephadex G-100 column. The cholesterol containing void volume fractions were pooled, concentrated and fractionated subsequently on the Biogel A $5 \mathrm{~m}$ column. In 13 patients an elution profile with two main peaks was seen (Fig. 1a). The first peak represented urinary cholesterol associated with membrane proteolipids which have been characterized previously [15]. The second peak was identified as HDL by immunodiffusion. In the remaining 6 patients the elution pattern revealed 3 peaks (Fig. $1 \mathrm{~b}$ ). The middle peak did contain LDL in only one urine sample and contained larger HDL aggregates in the others. Single values of urinary HDL-cholesterol were given in Table II. 
TABLE II

Urinary protein, cholesterol and HDL-cholesterol excretion in nephrotic patients

\begin{tabular}{lccl}
\hline Patients & $\begin{array}{c}\text { Protein } \\
(\mathrm{g} / 24 \mathrm{~h})\end{array}$ & $\begin{array}{c}\text { Cholesterol } \\
(\mathrm{mg} / \mathbf{2 4} \mathrm{h})\end{array}$ & $\begin{array}{l}\text { HDL-cholesterol } \\
(\mathrm{mg} / \mathbf{2 4} \mathrm{h})\end{array}$ \\
\hline 1. B.R. & 3.2 & 19.8 & 2.9 \\
2. B.M. & 24.5 & 57.9 & 1.7 \\
3. B.H. & 7.0 & 20.0 & 1.0 \\
4. D.A. & 6.9 & 12.2 & 0.7 \\
5. F.J. & 3.3 & 10.2 & 4.1 \\
6. H.W. & 4.1 & 5.9 & 0.1 \\
7. H.F. & 3.0 & 4.5 & 0.7 \\
8. H.A. & 3.1 & 6.2 & 0.1 \\
9. H.J. & 2.5 & 6.4 & 0.3 \\
10. K.A. & 4.9 & 24.6 & 7.6 \\
11. K.Z. & 5.1 & 9.8 & 3.1 \\
12. L.S. & 3.3 & 42.9 & 8.3 \\
13. L.A. & 8.2 & 68.7 & 0.2 \\
14. M.M. & 2.0 & 3.1 & 0.4 \\
15. N.F. & 21.0 & 42.8 & 5.0 \\
16. R.M. & 23.2 & 5.0 & 1.0 \\
17. S.J. & 18.3 & 38.0 & 1.4 \\
18. S.E. & 3.8 & 21.4 & 2.2 \\
19. W.C. & 7.7 & 21.5 & 0.9 \\
Range & $2.0-24.5$ & $3.1-68.7$ & $0.1-8.3$ \\
Median value & 4.9 & 20.0 & 1.0 \\
\hline
\end{tabular}

Serum-urine correlations

According to the statistical analysis the urinary total protein correlated significantly with urinary total cholesterol $(r=+0.76, p<0.01)$ (Fig. 2a). There was an

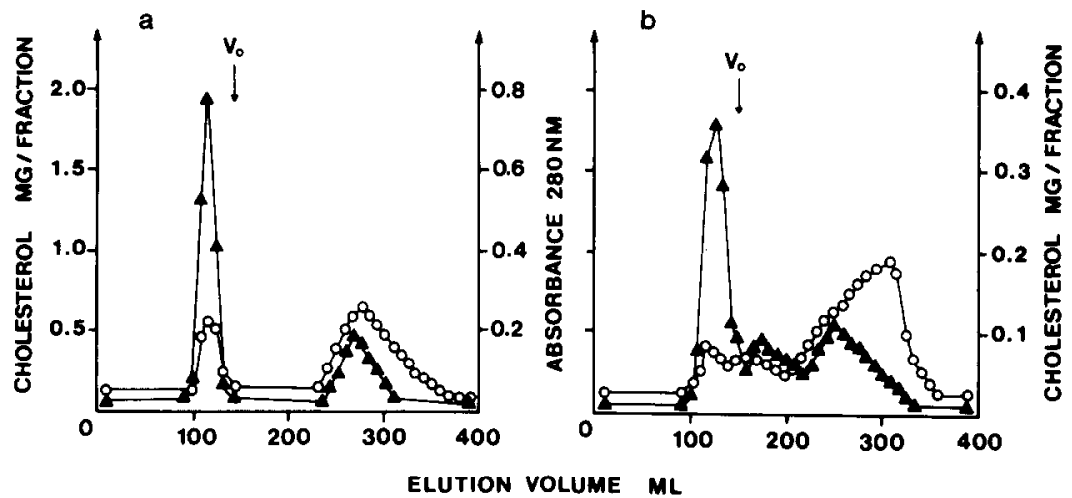

Fig. 1. a. Gel chromatographic elution pattern of a concentrated urinary sample on Biogel A $5 \mathrm{~m}$ (two peaks). b. Gel chromatographic elution pattern of a concentrated urinary sample on Biogel A $5 \mathrm{~m}$ (3 peaks). Column size $120 \times 1.8 \mathrm{~cm}$. Individual points represent total cholesterol concentrations (A-_— and the absorbance at $280 \mathrm{~nm}(\mathrm{O}-\mathrm{O})$ measured in each collected fraction. $\mathrm{V}_{\mathrm{o}}$, void volume. 
inverse correlation between serum albumin and serum total cholesterol $(r=-0.78$, $p<0.01$ ) (Fig. 2b) and a positive correlation between urinary HDL-cholesterol and serum LDL-cholesterol $(r=+0.54, p<0.05)$ (Fig. 2c). Urinary total protein and serum albumin $(r=-0.25)$, urinary total cholesterol and plasma total cholesterol $(r=+0.01)$, urinary HDL-cholesterol and plasma HDL-cholesterol $(r=+0.08)$
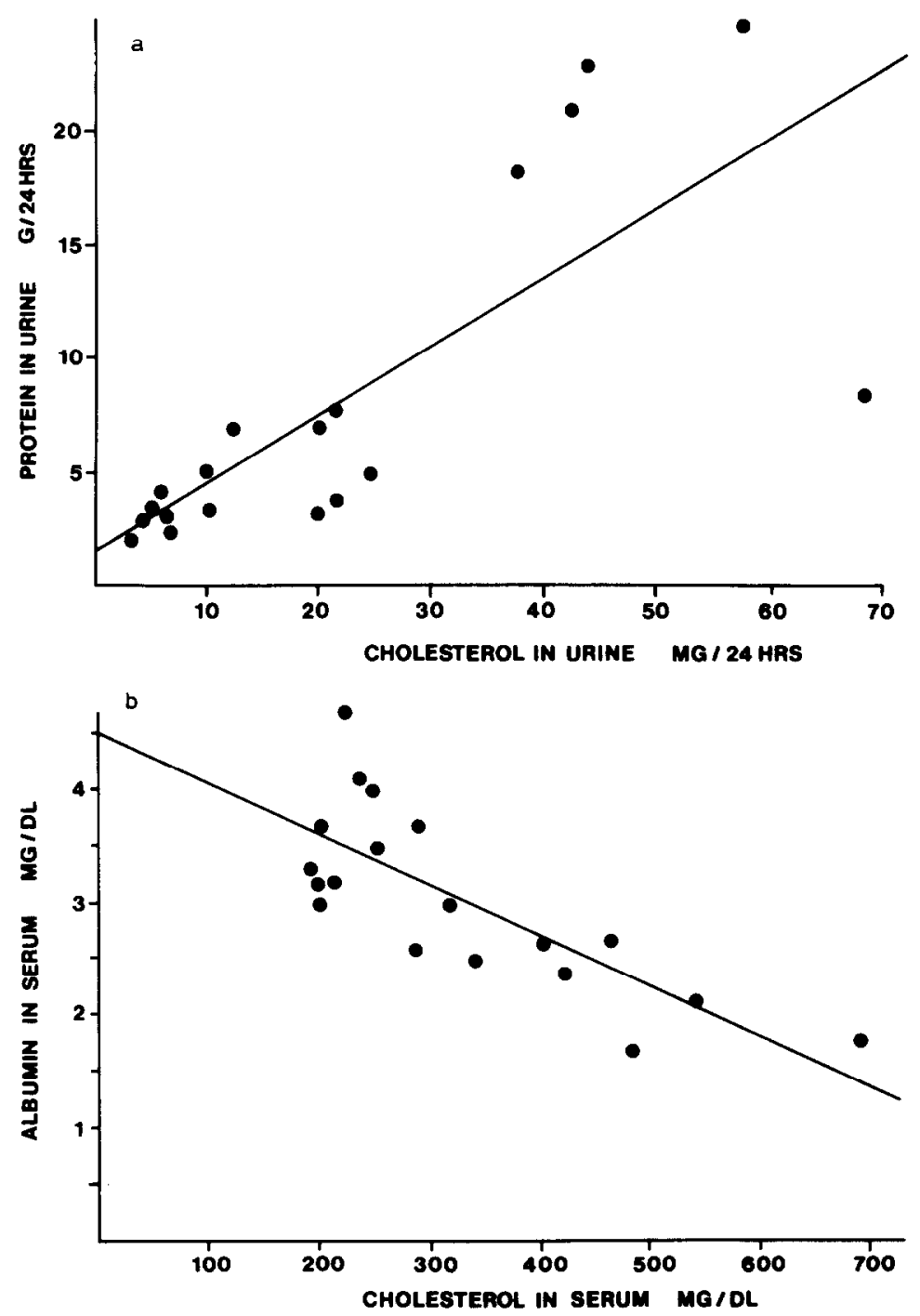

Fig. 2. a. Correlation between urinary protein and urinary total cholesterol $(r=+0.76, p<0.01)$, $y=0.29 x+1.58$. b. Correlation between serum albumin and serum total cholesterol $(r=-0.78, p<0.01)$, $y=-0.0045 x+4,5$. c. Correlation between urinary HDL-cholesterol and serum LDL-cholesterol ( $r=$ $+0.54, p<0.05), y=0.016 x-1$. 


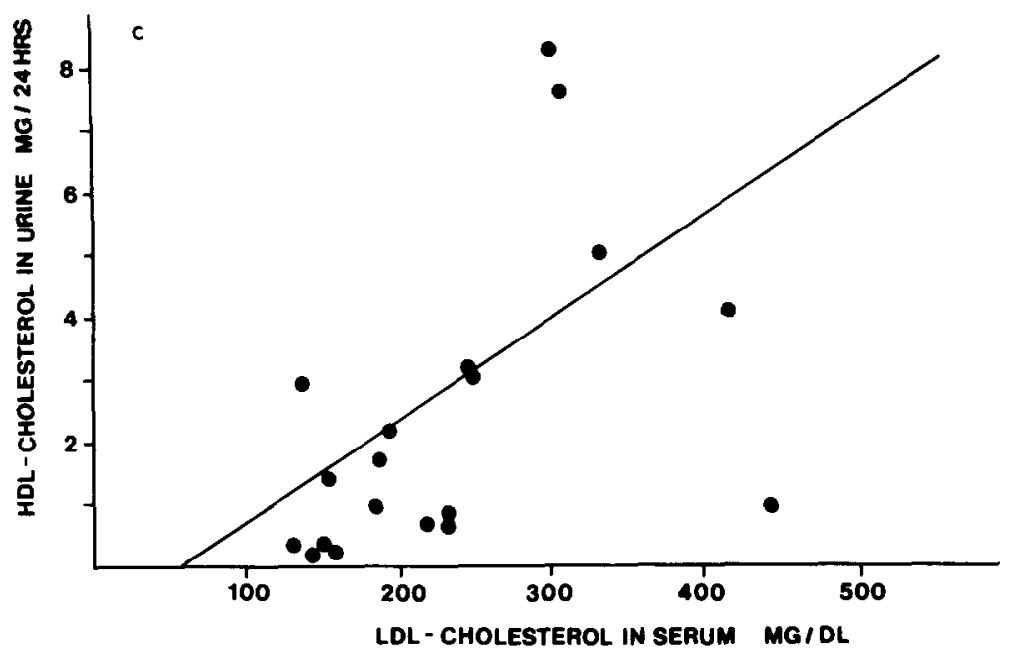

Fig. 2 (continued).

and plasma HDL-cholesterol and plasma LDL-cholesterol $(r=+0.48)$ did not correlate significantly.

\section{Discussion}

Abnormal serum lipid and lipoprotein patterns are commonly found in the nephrotic syndrome $[1,3]$. However, the etiology of hyperlipoproteinemia has not yet been clarified completely.

Our data confirmed altered serum lipoprotein concentrations in 17 and hypoalbuminemia in 14 of the 19 patients. Normal plasma cholesterol and triglyceride levels and a regular cholesterol distribution on the 3 main lipoprotein classes were found in one 17-yr-old man with a mild form of nephrotic syndrome, which had been diagnosed only $3 \mathrm{mth}$ ago, another patient showed a normal lipoprotein pattern. These findings are in variance with Chopra and coworkers [6], who reported normal serum lipoprotein profiles in 16 out of 33 patients. This discrepancy can be explained by the fact that in contrast to them only patients without steroid treatment were included in our study. Nine patients showed hyperlipoproteinemia phenotype IIb, 6 had phenotype IV and 2 phenotype IIa. The predominance of phenotype II and IV is confirmed by other investigators [3,6], although all phenotype of hyperlipoproteinemias can occur in the nephrotic syndrome. The presence of renal failure, special diets, the degree of hypoalbuminemia, age, sex and general condition of the patients or the etiology of nephrosis could be responsible for this heterogeneity $[1,3]$.

Only few studies exist which take the urinary lipid and protein excretion into account $[8,11]$. Using double immunodiffusion and lipoprotein-electrophoresis Kashyap et al found HDL in the urine of 9 nephrotic patients investigated. LDL 
was detected in only two of these patients with the nephrotic syndrome [11]. In our patients proteinuria up to $24.5 \mathrm{~g} / 24 \mathrm{~h}$ and cholesteroluria up to $68.7 \mathrm{mg} / 24 \mathrm{~h}$ were observed. After gel filtration of the concentrated urinary samples, besides the membrane proteolipids, which were eluted in the void volume fractions, HDL was regularly identified in the lower molecular weight peak fractions. Lipid recovery studies in single urinary specimens showed a total loss of urinary cholesterol between 30 and $50 \%$. Especially during the two ultrafiltration steps a considerable loss of lipids occurred most likely due to adherence of lipoproteins to the PM 10 membrane or to direct passage of free cholesterol molecules as a consequence of delipidation. Filtration using the Selecta filter $11171 / 2$ and gel chromatography did not remove more than $5 \%$ of total cholesterol.

The lipid-protein correlations in our study were in good accordance to the results published by other authors $[2,8,21,22]$. Urinary total protein and urinary total cholesterol correlated positively $(r=+0.76, p<0.01)$. There was a significant inverse correlation between albumin and total cholesterol in serum $(r=-0.78$, $p<0.01$ ). Apple et al reported similar results recently and suggested that albumin concentration and oncotic pressure might be closely related to the signal for enhanced hepatic production of lipoprotein lipids [21]. In discrepancy to Gherardi et al we found no reciprocal relation between serum HDL cholesterol and LDLcholesterol [3], but a positive correlation $(r=+0.54, p<0.05)$ between serum LDL-cholesterol and urinary HDL-cholesterol. It has been speculated that the selective increase in lipoprotein-cholesterol fractions other than HDL cholesterol may relate in part to loss of HDL in the urine of patients with nephrosis $[9,10]$. HDL serves as a flexible reservoir in plasma for the physiologically important apo C II molecules. These are activators of the lipoprotein lipase and influence the clearance of circulating triglycerides. Although LDL-cholesterol in serum and HDL-cholesterol in urine correlated positively in our study, the causative relationship of these findings is questionable. Our results demonstrate no inverse correlation between HDL-cholesterol in serum and urine. The absolute amount of HDL excreted in the $24 \mathrm{~h}$ urine is obviously too small to decrease the HDL concentrations in serum significantly. Therefore, our results are inconsistent with the hypothesis [23] that the urinary loss of HDL might relate to the hyperlipidemia of nephrotic syndrome.

\section{Acknowledgements}

The skilful technical assistance of Ms. B. Zündt is gratefully acknowledged.

\section{References}

1 Baxter JH, Goodman HC, Havel RI. Serum lipids and lipoprotein alterations in nephrosis. J Clin Invest 1960;39:455-465.

2 Baxter JH. Hyperlipoproteinemia in nephrosis. Arch Intern Med 1962;109:146-161.

3 Gherardi E, Rota E, Calandra S, Genova R, Tamborino A. Relationship among the concentrations of serum lipoproteins and changes in their chemical composition in patients with untreated nephrotic syndrome in man. Eur J Clin Invest 1977;7:563-570. 
4 Wada M, Minamisono T, Akamatsu A, Okabe M, Morita T, Handa Y, Unoki T. Serum lipid and lipoprotein abnormalities in major clinical entities of renal disease. Contr Nephrol 1978;9:61-68.

5 Ohta T, Matsuda I. Lipid and apolipoprotein levels in patients with nephrotic syndrome. Clin Chim Acta 1981;117:133-143.

6 Chopra JS, Malick NP. Hyperlipoproteinemias in nephrotic syndrome. Lancet 1971;13:317-321.

7 Jüngst D, Wallner J, Karl HJ. Correlation of total cholesterol and protein in urine in patients with the nephrotic syndrome. Klin Wochenschr 1980;58:1215-1216.

$8 \mathrm{Klahr} S$, Tripathy $\mathrm{K}$, Bolanos $\mathrm{O}$. Qualitative and quantitative analysis of urinary lipids in the nephrotic syndrome. J Clin Invest 1967;16:1475-1481.

9 De Mendoza SG, Kashyap ML, Chen CY, Lutmer RF. High density lipoproteinuria in nephrotic syndrome. Metabolism 1976;25:1143-1150.

10 Felts JM, Mayerle JA. Urinary loss of plasma high density lipoprotein-a possible cause of the hyperlipidemia of the nephrotic syndrome. Circulation 1974;49+50, Suppl. 3:III-263 (abstract).

11 Kashryap ML, Ooi BS, Hynd BA, Glueck CJ, Pollak VE, Robinson K. Sequestration and excretion of high density and low density lipoproteins by the kidney in human nephrotic syndrome. Artery 1979;6:108-121.

12 Röschlau P, Bernt E, Gruber W. Enzymatische Bestimmung des Gesamt-Cholesterins im Serum. Z Klin Chem Klin Biochem 1974;12:403-407.

13 Eggstein M. Eine neue Bestimmung der Neutralfette im Blutserum und Gewebe. Klin Wochenschr 1966;44:267-273.

14 Weichselbaum TE. An accurate and rapid method for the determination of proteins in small amounts of blood serum and plasma. Amer J Clin Path Techn Bull 1946;10:40-49.

15 Jüngst $D$, Weiser $H$, Siess E, Karl HJ. Urinary cholesterol: its association with a macromolecular protein-lipid complex. J. Lipid Res 1984;25:655-664.

16 Havel RJ, Eder AH, Bragdon JH. The distribution and chemical composition of ultracentrifugally separated lipoproteins in human serum. J Clin Invest 1955;109:742-757.

17 Lopes-Virella UF, Stone P, Ellis S, Colwell JA. Cholesterol determination in high density lipoproteins separated by three different methods. Clin Chem 1977;23:882-884.

18 Tamm I, Horsfall FL. A mucoprotein derived from human urine with influenza, mumps, and Newcastle disease viruses. J Exp Med 1952;95:71-97.

19 Sata D, Havel RJ, Jones AL. Characterization of subfractions of triglyceride-rich lipoproteins separated by gelchromatography from blood plasma of normolipemic and hyperlipemic humans. $J$ Lipid Res 1972;13:757-768.

20 Sachs L. Der Spearmansche Rangkorrelationskoeffizient. In: Sachs L, ed. Angewandte Statistik. Berlin: Springer-Verlag, 1978;309-312.

21 Appel GB, Blum CB, Chien S, Kunis CL, Appel AS. The hyperlipidemia of the nephrotic syndrome. Relations to plasma albumin concentrations, oncotic pressure, and viscosity. $N$ Engl $J$ Med 1985;312:1544-1548.

22 Newmark SR, Anderson RF, Donadoi IV, Ellefson RD. Lipoprotein profiles in adult nephrotics. Mayo Clin Proc 1975;50:359-364.

23 Gherardi E, Vecchia L, Calandra S. Experimental nephrotic syndrome in the rat induced by puromycin aminonucleoside. Exp Molec Pathol 1980;32:128-142. 